\title{
Urban Seismic Risk Analysis Using Empirical Fragility Curves for Kerend-e-Gharb After Mw 7.3, 2017 Iran Earthquake
}

Mahnoosh Biglari ( $D$ mahnooshbiglari@yahoo.com )

Razi University https://orcid.org/0000-0002-1245-7740

Antonio Formisano

University of Naples Federico II: Universita degli Studi di Napoli Federico II

\section{Research Article}

Keywords: Urban seismic vulnerability, Population damage, Economic cost, Debris, Real earthquake verification

Posted Date: October 19th, 2021

DOI: https://doi.org/10.21203/rs.3.rs-981458/v1

License: (c) (i) This work is licensed under a Creative Commons Attribution 4.0 International License.

Read Full License 


\title{
Urban Seismic Risk Analysis Using Empirical Fragility Curves for Kerend-e-gharb after Mw 7.3, 2017 Iran Earthquake
}

Concise Title: Urban seismic risk analysis

Author 1: Mahnoosh Biglari (Corresponding Author)

Assistant Professor, Civil Engineering Department, School of Engineering, Razi University, Kermanshah, Iran, Member of IEEA. P.O.Box: 67149-67346.

Email: m.biglari@ razi.ac.ir, mahnooshbiglari@yahoo.com.

ORCID: 0000-0002-1245-7740

Author 2: Antonio Formisano

Associate Professor, Department of Structures for Engineering and Architecture, School of Polytechnic and Basic Sciences, University of Naples Federico II, Naples, Italy.

Email: antoform@unina.it

ORCID: 0000-0003-3592-4011

\begin{abstract}
This study provides the seismic risk map of the small mountain city of Kerend-e-gharb. This innovative study evaluates the existing methods and formulations with the effects of a devastating earthquake using empirical fragility curves. A seismic vulnerability map is developed at the urban block-scale at a Geographic Information System for a variety of steel, reinforced concrete, confined masonry, unreinforced masonry, and adobe residential buildings. The estimated seismic damages are validated by comparing them with the surveyed building damages in the Sarpol-ezahab earthquake. Moreover, the damages to the population, including the probability of homelessness, death, severe injuries that need immediate hospital treatment, moderate injuries that require hospital treatment, and light injuries without hospitalization, are assessed. This research also investigated the economic losses and estimation of debris. Finally, the mean damage index
\end{abstract}


map is presented. The mean damage index map is modified due to renovation and retrofitting at higher damage levels, and it is increased at moderate damage levels that have not been structurally improved. The results of this study can be used in seismic crisis management planning in natural hazards to achieve a sustainable city.

Keywords: Urban seismic vulnerability, Population damage, Economic cost, Debris, Real earthquake verification. 


\section{Introduction}

Seismic risk is the combination of hazard, vulnerability, and value of an element or area affected by an earthquake. This seismic vulnerability is defined as the probability of a particular damage state due to the earthquake event during a specified return period. This can be seen in a Geographic Information System (GIS) framework, which displays the estimated damage from a particular earthquake. Although these definitions only apply to structural features, building damage can result in population and economic loss.

On an urban scale, the goal of seismic risk assessment could be urban macro-management, prioritization of retrofitting vulnerable buildings, and crisis management. This assessment is a scientific tool to reduce urban seismic risk and earthquake crisis management to provide temporary accommodation centers, hospital services, insurance, and debris depots. Statistics and information on residential buildings and essential structures are often crucial in large earthquake-prone cities. These data are collected and processed at various knowledge levels (from urban visual to structural system identifications) to estimate the seismic risk. Comprehensive projects, such as HAZUS (1999) in the United States and RISK-UE (Mouroux and Brun, 2008) in Europe, provided a good platform for seismic risk assessment based on ground earthquake microzonation and structural seismic vulnerability assessment. The applicability of these frameworks was demonstrated in cities and regions worldwide, including Bucharest (Lungu et al., 2004), Catania (Faccioli et al., 2004), Sofia (Kostov et al., 2004), Thessaloniki (Kappos et al., 2008), Barcelona (Lantada et al., 2010), Coimbra (Vicente et al., 2011), Al-Hoceima (Cherif et al., 2016), Sion and Martigny (Lestuzzi et al., 2016), Bhaktapur (Gautam and Rodrigues, 2018), Kermanshah (Biglari et al., 2018), Timisoara (Mosoarca et al., 2019), and Molise Region of Italy (Chieffo and Formisano, 2020). 
One of the essential tools in seismic risk assessment is fragility curves. Most of the fragility curves have been developed based on the analytical method on the specific type of structure or indirect method from rapid urban assessment data. There are rare cases of seismic risk assessment on an urban scale that have been studied in a city that has previously been devastated by a major earthquake to validate common methods and hypotheses. This was conducted in the current study, which evaluated the seismic risk of Kerend-e-gharb, one of the cities devastated by the 2017 November $12(\mathrm{Mw}$ 7.3) Sarpol-e-zahab earthquake. The results are managed using a GIS tool. Among a list of the Sarpol-e-zahab earthquake-affected cities, this city is selected because it is located on rocky land and experienced the maximum acceleration equal to peak design acceleration based on the IRSt2800 (2015) standard. The seismic damages of various types of structures are studied, including steel (ST), reinforced concrete (RC), confined masonry (CM), unreinforced masonry (URM), and adobe (Ad). Empirical fragility curves, developed on the damage data of the 2017 Sarpol-e-zahab earthquake in the large area affected by the earthquake, were the basis for seismic vulnerability, structural and population damage, and economic loss assessment.

\section{The urban area}

Kerend-e-gharb is the capital of Dalahu County in Kermanshah Province, Iran (Figure 1a). At the 2016 census, its population was 7,798, in 2,349 families. It has an area of about $2.2 \mathrm{~km}^{2}$ and an average density of 3,545 inhabitants per $\mathrm{km}^{2}$. The new city of Kerend-e-gharb (Figure 1b) was built in the late Qajar period to develop urbanization on the site of the ancient city of Kerend. The city center is located in the Dalahu Mountain valley (Figure 1c). During the past 40 years, the city developed in the northeast, the west, and the southeast of the valley. Dalahu Mountain is a part of the Zagros Mountains of the Zagros seismotectonic area. Seismic activity of 4 active faults, namely; Main Zagros Reverse Fault (MZF), High Zagros Fault (HZF), Mountain Front Fault 
(MFF), and Zagros Foredeep Fault (ZFF) (Hessami et al., 2003) (yellow lines in Figure 1a), are the earthquake triggers in Kermanshah province. A rupture caused the 2017 Sarpol-e-zahab earthquake (Ashayeri et al., 2019; Ashayeri et al., 2020; Ashayeri et al., 2021) in the MFF.

The Sarpol-e-zahab earthquake caused a peak ground acceleration (PGA) of 283 gals in this city. The accelerograms of this earthquake were recorded in the KRD station of Iran Strong Motion Network (ISMN, provided by Road, Housing, \& Urban Development Research Center). Since this event's peak ground acceleration (PGA) is equal to the one suggested by the IRSt2800 (2015) standard for this city, this case is fit to assess the urban seismic risk.

The population and housing census statistics data were collected in 2016 by the Statistical Center of Iran (SCI). The city is subdivided into six areas, each containing several blocks (384 blocks in total) (Figure 1d). All the available data is integrated into a Geographic Information System (GIS), represented by QGIS (2014) in this study. QGIS (2014) is a free and open-source cross-platform desktop GIS that supports viewing, editing, and analyzing geospatial. 

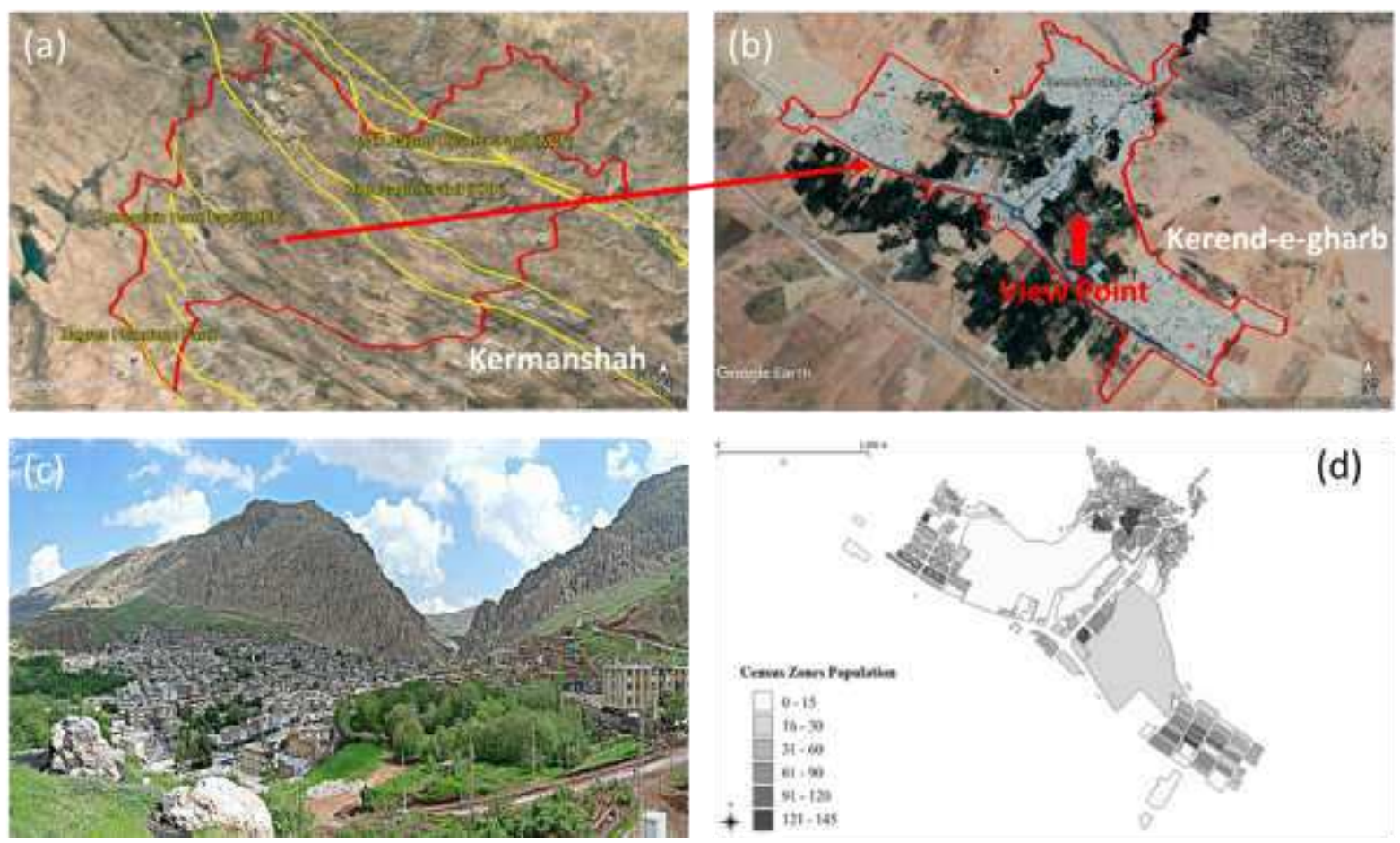

(d)

Figure 1 a) Kermanshah province at the west of Iran (yellow solid lines show active faults) (Google Earth); b) Bird-eye view of Kerend-e-gharb city (Google Earth); c) South to north view of Kerend-e-gharb city; d) population density for the census zones of Kerend-e-gharb

\section{Database of buildings}

The official statistic of the Statistical Center of Iran (SCI) in 2016 shows that Kerend-e-gharb has 2,289 houses. Among which 282 buildings are short-to-medium height apartments, and 2007 buildings are non-apartment buildings. Figure 2a shows the frequency of buildings for the covered area. It is noticed that $69 \%$ of the buildings have an area between 76 and $150 \mathrm{~m}^{2}$.

This database provided detailed information concerning the structural typology of buildings. The buildings in Kerend-e-gharb are divided into five main categories:

- Steel structures (ST), including braced frames, moment-resisting frames, and a combination of both moment-resisting frames and braced frames;

- Reinforced concrete structures (RC), such as moment-resisting frames, and a combination of moment-resisting frames and RC shear walls; 
- Confined masonry structures (CM) (by steel or concrete ties);

- Unreinforced masonry structures (URM) (with brick or concrete block walls and wooden or steel beams),

- Adobe structures (Ad).

The pie chart shown in Figure $2 b$ shows the percentage of each of these categories.

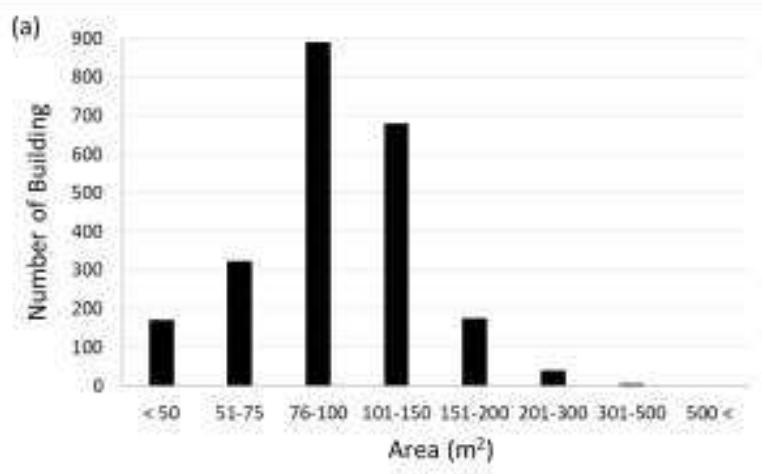

(b)

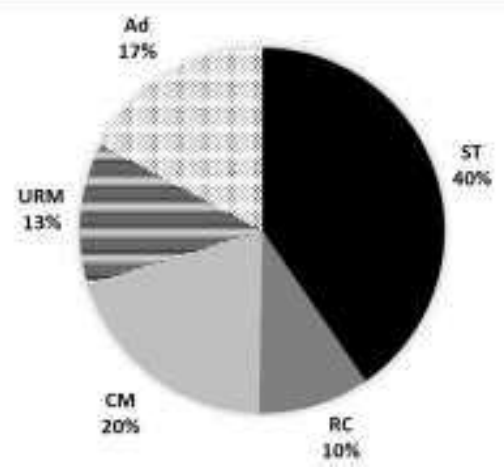

Figure 2 a) The frequency of buildings in each range of area, and b) percentage of various structural types

Figure 3a shows the percentage of the total engineered structures (ST and RC) in each urban block on the GIS map of the city. Figure $3 \mathrm{~b}$ also shows the percentage of total structures without lateral load-bearing systems (CM, URM, and Ad) in the urban block scale. The structural texture of the city in the central and the northeastern parts mainly contains CM, URM, and Ad structures. Recently developed areas in the southeast and the west generally are covered with ST and RC structures. The higher amount of non-engineered buildings, the higher the seismic vulnerability. The seismic vulnerability of urban blocks is investigated in the next section using fragility curves. 


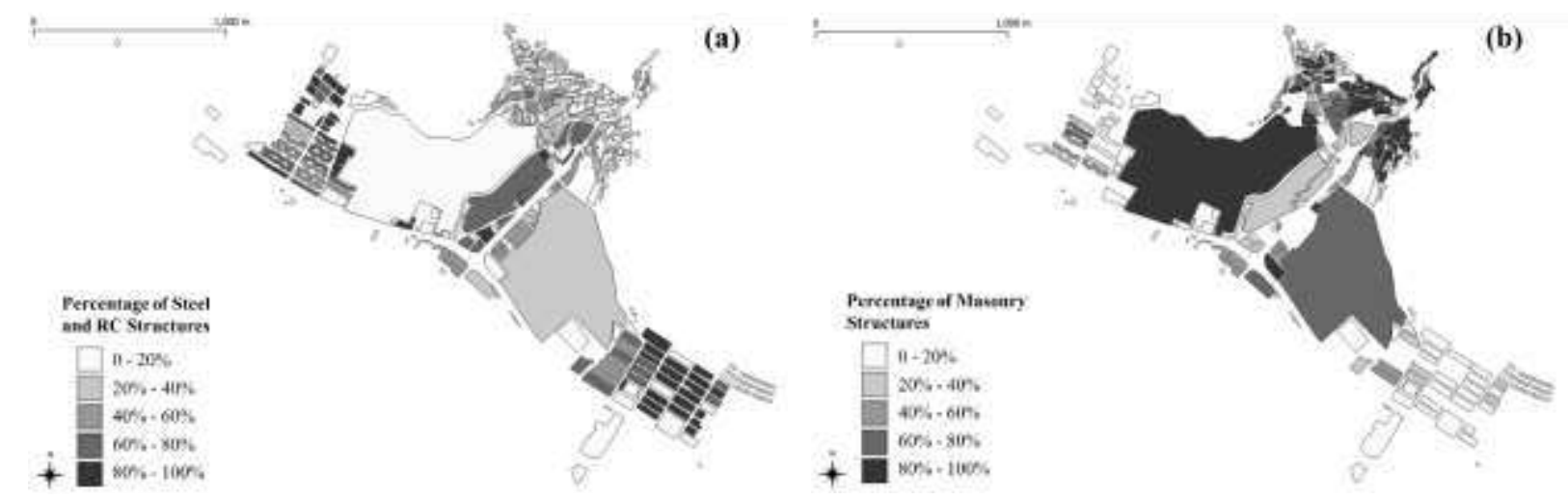

Figure 3 a) Percentage of engineered Steel and RC structures per blocks, b) percentage of masonry structures per block

\section{Seismic vulnerability assessment}

Seismic fragility curves represent the probability of damage in specific ground motion. Fragility curves are defined as the probability of exceeding a certain damage level or state, $D k(k=0,1,2$, $3,4,5$, or $k=0,1,2,3,4)$. They are influenced by the parameter of the specific distribution function (i.e., beta distribution, binomial distribution, or standard normal distribution). These fragility curves allow estimating the damage probability for the specific structural typology. The European Macroseismic Scale (EMS-98) (Grünthal, 1998) with five damage states is used in this study. These states of damages are defined by Grünthal (1998) as; $D 0=$ none, $D l=$ slight (no structural damage and slight non-structural damage), $D 2=$ moderate (slight structural damage and moderate non-structural damage), D3= heavy (moderate structural damage and heavy non-structural damage), $D 4=$ very heavy (heavy structural damage and very heavy non-structural damage), and $D 5=$ destruction (very heavy structural damage). The empirical seismic fragility curves are used to determine the damage states probability, $P(D k)$. These curves have been proposed for damage data of the Sarpol-e-zahab earthquake from buildings with similar materials and construction methodology. Hence, these are proper choices to evaluate the seismic damage states of buildings in this city. The applied seismic empirical fragility curves for steel and reinforced structures were 
developed by Biglari et al. (2021), for confined masonry and unreinforced masonry structures were designed by Biglari and Formisano (2020), and for adobe structures were given by Omidvar et al. (2012).

The vulnerability index is a normalized score between 0 and 1 that presents the seismic building behavior. The closer the index is to 1 , the more seismic vulnerable the structure is. Meanwhile, the closer the index is to zero, the less seismic vulnerable the structure is. Table 1 shows the vulnerability indices $(\mathrm{Vi})$ for different structural typologies. As shown in Equation 1 (found in Milutinovic and Trendafiloski (2003)), the discrete probability of damage state $k, P(D k)$, are derived from the difference of cumulative probabilities $P_{D}(k)$.

$$
P(D k)=P_{D}(k+1)-P_{D}(k)
$$

Table 1 Vulnerability index (Vi) for different typologies

\begin{tabular}{cccccc}
\hline Type & $\mathrm{ST}^{*}$ & $\mathrm{RC}^{*}$ & $\mathrm{CM}^{* *}$ & $\mathrm{URM}^{* * *}$ & $\mathrm{Ad}^{* * * *}$ \\
\hline Proposed $\mathrm{Vi}$ & 0.54 & 0.58 & 0.52 & 0.62 & 0.9 \\
\hline
\end{tabular}

${ }^{*}$ After Biglari et al. (2021)

** After Biglari and Formisano (2020)

${ }^{* * * *}$ After Omidvar et al. (2012)

As an overview, Figure 4 shows the number of buildings suffering each level of damage. This indicates that most of the buildings of this city in the face of PGA=283 gals suffer slight $(D 1)$ damage state to moderate (D2) damage states. These calculations were performed on a block scale. 


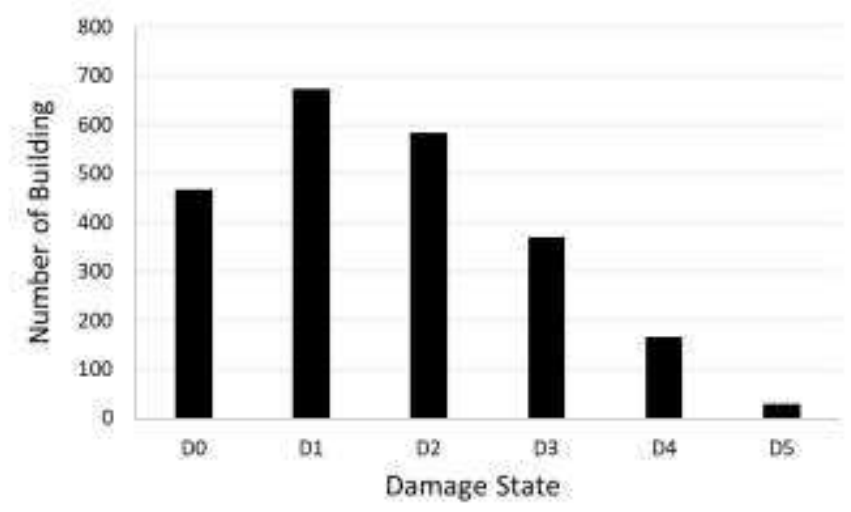

Figure 4 Different damage states suffered by the population of investigated buildings

Figure 5 shows the probability of vulnerability at damage levels from $D 0$ to $D 5$ on a block scale. Figure 5 shows the probability of vulnerability at damage levels from $D O$ to $D 5$ on a block scale. These damage probabilities are estimated by the $\mathrm{PGA}=283$ gals equal to the peak ground acceleration recorded in the Iran Strong Motion Network station of the Kerend-e-gharb city by the Mw 7.3 Sarpol-e-zahab earthquake.

Low damage states (D1 and D2) are more common in the recently built regions (i.e., the southeast and the west of the city), which are much more covered by ST and RC engineering buildings (Figures $5 \mathrm{~b}$ and $5 \mathrm{c})$. The severe damage states (D4 and D5) happen in the northeastern part of the city that there are more masonry buildings (Figures 5e and 5f).
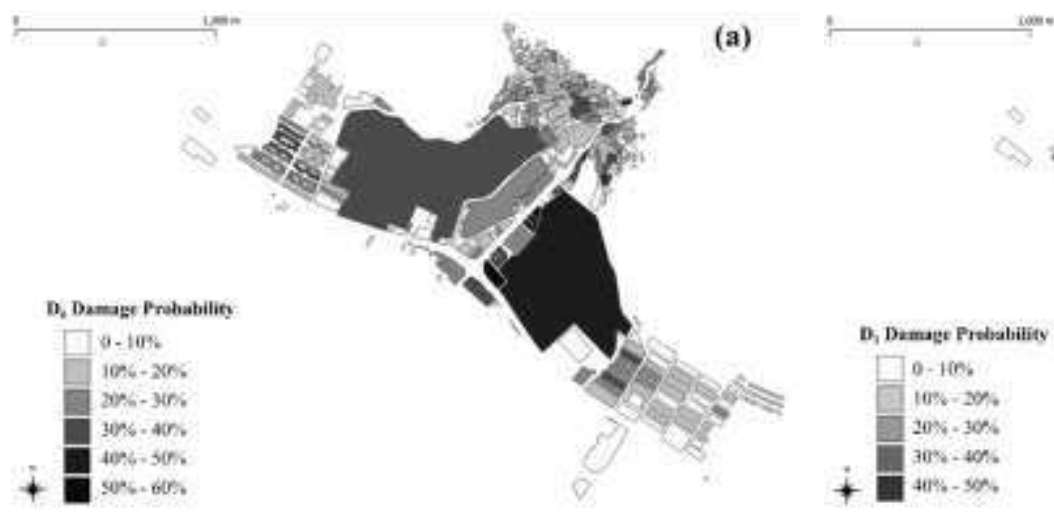

(b) 

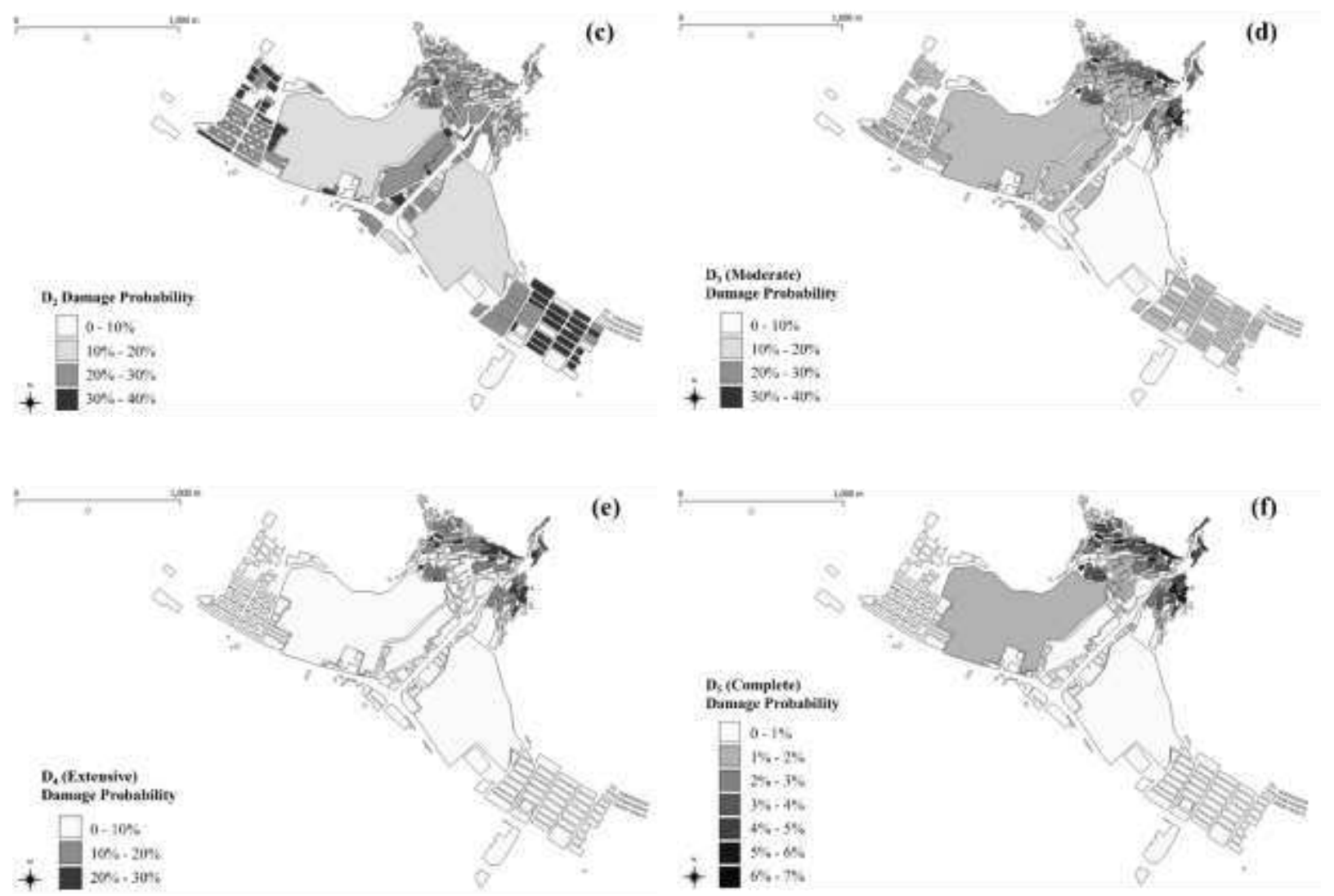

Figure 5 Probability of damage grade per block: a) $D 0$, b) $D 1$, c) $D 2$, d) $D 3$, e) $D 4$, and f) $D 5$

Here eight different typology buildings from (Kalantari et al., 2019) have been selected for validation of the results. Figure 6 shows the location of target buildings. Damage caused by the Sarpol-e-zahab earthquake in these buildings has been collected and compared to the predictive damage derived from fragility curves. Table 2 presents the typologies of the target buildings along with the observed damage grade and the most probable damage grade determined from Figure 5. It shows that there is a good agreement between the fragility curves analysis results and the earthquake experienced. The photo of the building shown in Figure 6 belongs to case No. 2. This building is a five-story steel structure, which in one direction has braced frames and in a 
perpendicular direction has moment-resisting frames. There is no structural damage on the building due to the earthquake, and only slight non-structural damage happened. Facade stones (highlighted by yellow circles in Figure 6) have collapsed due to a lack of screwing to the back wall (damage state $D 1$ ). Another example in the southeastern region of the city is a six-story steel building (No. 4). This building in one direction has braced frames and in a perpendicular direction has moment-resisting frames. There is no structural damage due to the peak acceleration of 283 gals, but slight non-structural damage has been seen on it (damage state D1). Building No. 5 is one story confined masonry structure that neither structural nor non-structural damages have at the peak acceleration of 283 gals (damage state $D 0$ ). Buildings No. 6 and No. 7 are similar in typology, but Building No. 7 has more weaknesses in ceilings and walls. There is no structural damage, but slight non-structural damage happened by a recorded earthquake (damage state D1). Finally, building No. 8 is an example of an adobe structure that, surprisingly, did not have any structural and non-structural damage after this earthquake (damage state $D 0$ ). 


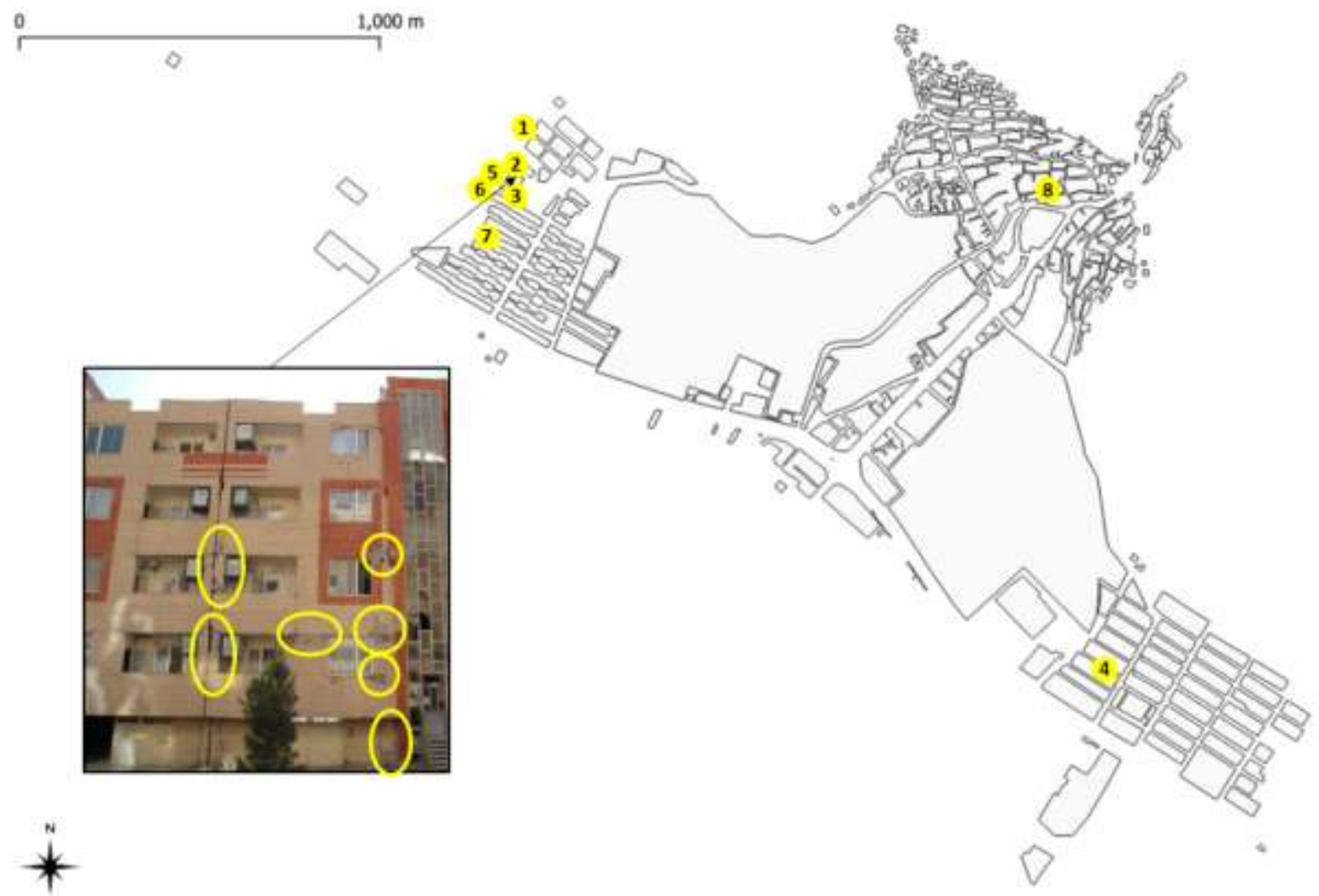

Figure 6 Location of target buildings

Table 2 Target buildings typologies and observed damage state

\begin{tabular}{lcccccccc}
\hline No. & 1 & 2 & 3 & 4 & 5 & 6 & 7 & 8 \\
\hline Typology & ST & ST & ST & ST & CM & URM & URM & Ad \\
\hline Observed structural damage (\%) & 0 & 0 & 0 & 0 & 0 & 0 & 20 & 0 \\
\hline Most probable damage grade* & $D 1$ & $D 1$ & $D 1$ & $D 1$ & $D 0$ & $D 1$ & $D 1$ & $D 0$ \\
\hline "From Figure 5 & & & & & & & &
\end{tabular}

It is possible to define the structural collapse probability and unusable structure probability at the block scale in the GIS map. In Italy, Bramerini et al. (1995) proposed two expressions, illustrated in Equations 2 and 3, for estimating collapsed and unusable buildings, respectively.

$$
\begin{gathered}
P_{\text {collapse }}=P(D 5) \\
P_{\text {unusable buildings }}=P(D 3) \times W_{u n, 3}+P(D 4) \times W_{u b, 4}
\end{gathered}
$$


where $P(D k)$ is the occurrence probability of a specific damage state (Dl to $D 5)$, and $W_{u b, 3}$ and $W_{u b, 4}$ are weights for considering unusable buildings that indicate the percentage of buildings associated with the damage state D3 and damage state D4, respectively. Bramerini et al. (1995) suggested the weighting factors values. $W_{u b, 3}=0.4$, and $W_{u b, 4}=0.6$ were applied to analyze the Kerend-e-gharb earthquake.

Figures $7 \mathrm{a}$ and $7 \mathrm{~b}$ show the collapsed buildings probability and the probability of unusable buildings, respectively. The blocks in the northeastern with a high percentage of masonry buildings are more likely to collapse and unusability.

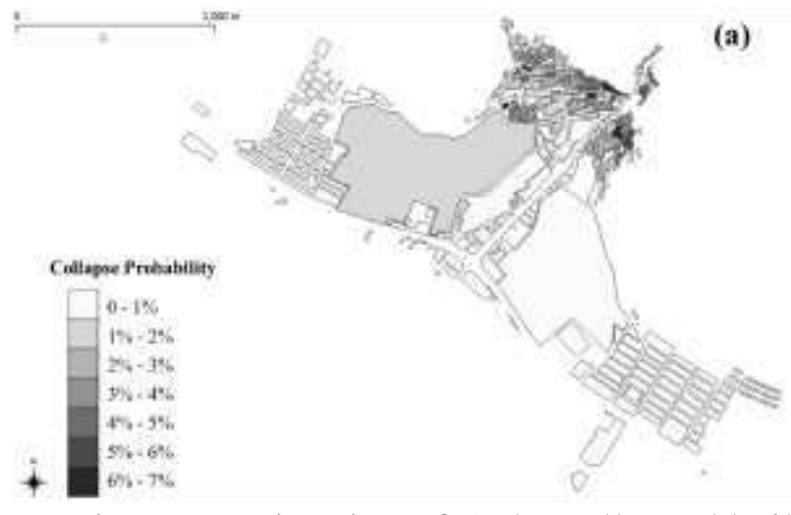

Figure 7 Estimation of a) the collapsed buildings probabilities and b) unusable buildings probabilities per block

\section{Damage to population}

There are different approaches for assessing the damage to the population. In Italy, Bramerini et al. (1995) developed a method to estimate the homeless probability. Equation 4 from (1995) presents the homeless probability. Figure 8 shows the homelessness probability for each block.

$$
P_{\text {homeless }}=P(D 3) \times W_{u b, 3}+P(D 4) \times W_{u b, 4}+P(D 5) \times 0.7
$$


The homeless probability can be used for a post-earthquake emergency plan based on the people's social culture. This can help determine the number of temporary shelters needed to house the homeless people, the location of temporary accommodations, and the store of the basic facilities (e.g., drinking water, dry and canned food, heating appliances, clothes, and blankets). Often, after an earthquake, homeless people tend to live as close to their former damaged home to protect the remnants of their home appliances.

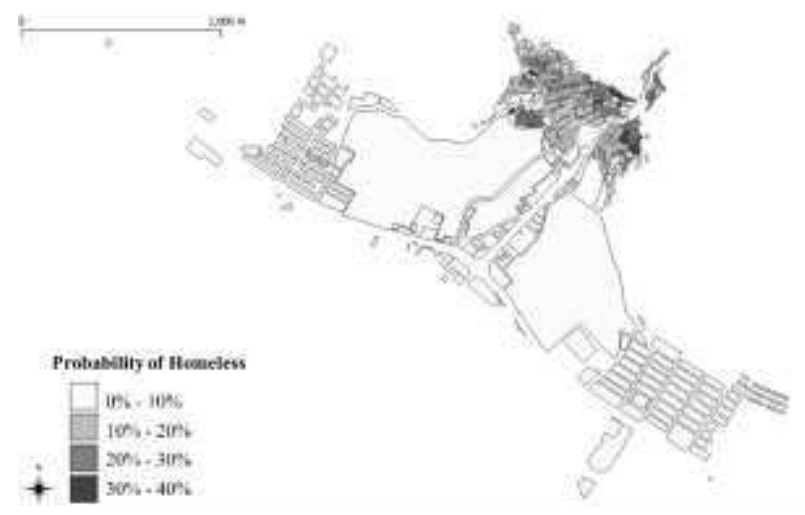

Figure 8 Homeless probabilities per block

On the other hand, to evaluate the probability of deaths and injuries to the population caused by an earthquake, the casualty model presented by Coburn et al. (1992) is applied at blocks. The casualty model of Coburn et al. (1992) was presented based on the collected worldwide database of 1100 earthquakes that caused life loss.

In this model, the number of casualties (Ks) depend on the number of collapsed buildings (D5) and is directly proportional to parameters such as;

- Inhabitants number per building (M1),

- Occupancy at the time of the earthquake (M2),

- Percentage of trapped occupants by collapse (M3),

- Percentage of mortality among trapped occupants (M4), and 
- Post-collapse mortality (M5).

Equation 5 presents the casualty model given by Coburn et al. (1992):

$$
K s=D_{5}[M 1 \times M 2 \times M 3 \times(M 4+M 5 \times(1-M 4))]
$$

Table 3 presents the adopted values for the factors M2 to M5 for different cases of casualties. These are including; dead people and unsavable and severely injured that need immediate medical attention, moderately injured that need hospital treatment, and lightly injured that are not demanded hospitalization. The earthquake struck at 21:48 on November 12 (in the fall); thus, the factor M2 based on the curve for standard occupancy of residential buildings by the urban population at the same time is $80 \%$. The distance from the Kerend-e-gharb city to the epicenter of the earthquake is about 66 kilometers. The recorded velocity of this earthquake in the city of Kerend-e-gharb showed near-field effects. As a result, the M3 factor for both RC and ST constructions is 70 percent, while the M3 factor for masonry structures is 30 percent (for the intensity of VIII). The M3 factor is equal to $30 \%$ for masonry structures (for intensity VIII). The M4 factor is considered the same as the values suggested by Coburn et al. (1992). Finally, the M5 factor is the same proposed by Coburn et al. (1992) for a community capable of organizing rescue activities.

Table 3 Assumed values for the factors of Equation 5 (adapted from Coburn et al. (1992))

\begin{tabular}{|c|c|c|c|c|c|c|c|}
\hline \multirow[b]{2}{*}{ Typology } & \multirow{2}{*}{$\begin{array}{l}\text { M2 } \\
(\%)\end{array}$} & \multirow{2}{*}{$\begin{array}{l}\text { M3 } \\
(\%)\end{array}$} & \multicolumn{4}{|c|}{ M4 (\%) } & \multirow{2}{*}{$\begin{array}{l}\text { M5 } \\
(\%)\end{array}$} \\
\hline & & & $\begin{array}{c}\text { Dead or } \\
\text { unsavable }\end{array}$ & Severe injury & Moderate injury & Light injury & \\
\hline $\mathrm{RC}$ and $\mathrm{ST}$ & 80 & 70 & 40 & 10 & 40 & 10 & 90 \\
\hline $\begin{array}{l}\text { CM, URM, } \\
\text { and Ad }\end{array}$ & 80 & 30 & 20 & 30 & 30 & 20 & 60 \\
\hline
\end{tabular}

Figures $9 \mathrm{a}$ to $9 \mathrm{~d}$ show the per-block distribution of the probability of dead and unsavable persons, severely injured, moderately injured, and lightly injured people. The results show that the highest 
probability of dead and unsavable people is in the northeastern and central parts of the city. In these areas, in addition to recommending the retrofitting of buildings, the construction of medical centers and rescue stations can also aid with on-time rescue and risk reduction.
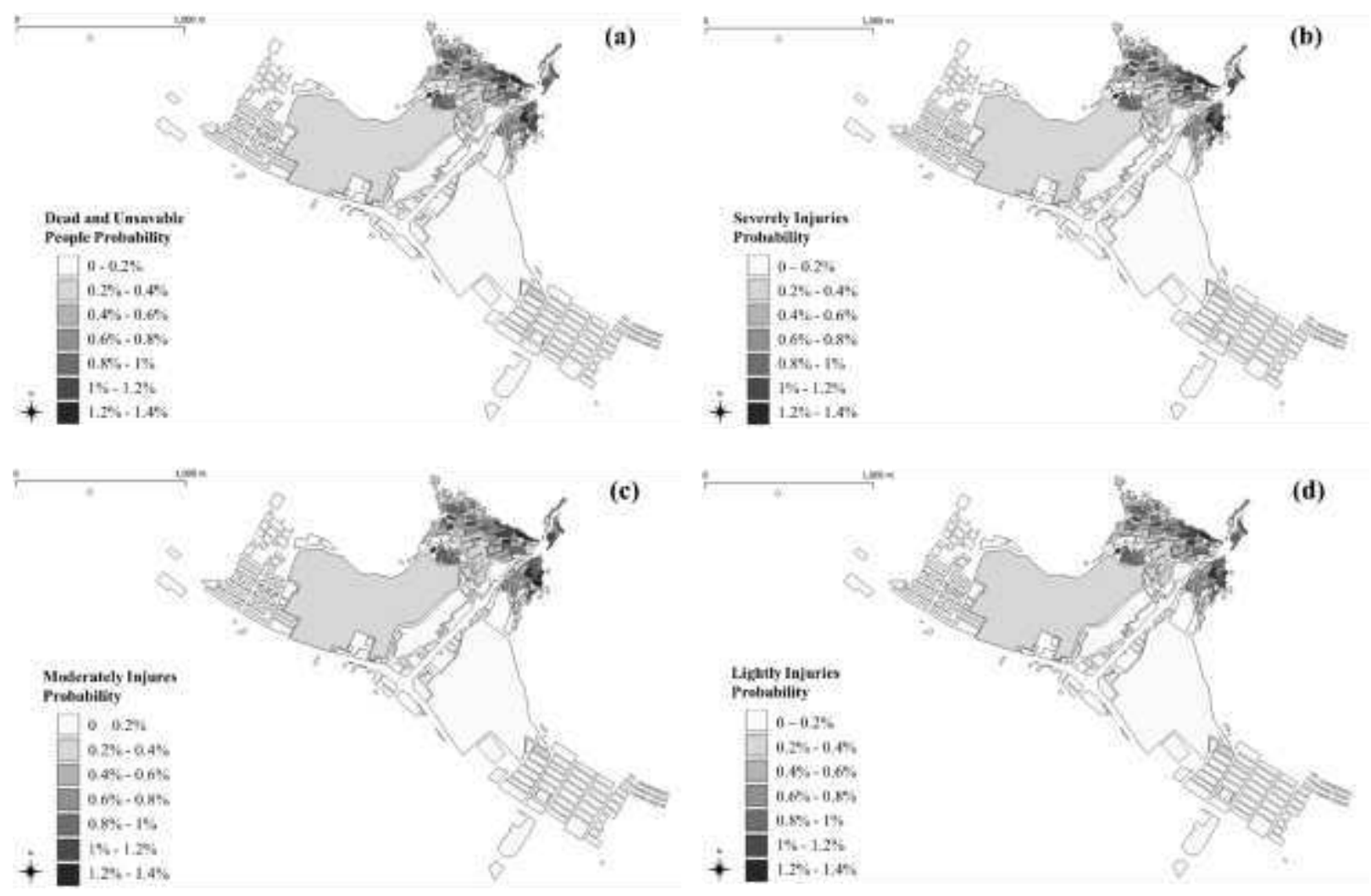

Figure 9 Distribution of the probability of a) dead and unsavable people, b) severely injuries, c) moderately injuries, and d) lightly injuries per block.

The post-earthquake number of dead, verify the prediction made. The earthquake at Sarpol-ezahab caused no casualties in this city. On the other hand, the probability of death in this city is less than $1.4 \%$.

\section{Economic cost}

The construction sector in Iran has a very high inflation rate. Inflation has risen in recent years as a result of economic crises in Iran caused about by sanctions. In general, economic loss is defined 
as the cost of replacing damaged buildings with ST or RC buildings constructed by the latest earthquake-resistant standards. The cost of constructing a ST or RC building per square meter (excluding land cost) in the years following the Sarpol-e-zahab earthquake (from 2017 to 2021) has been incredibly diverse (for a standard building from about ten million Rials to forty-five million Rials).Two economic cost scenarios are evaluated; the first is the absolute (and subsequently the total) cost in 1000 million Rials, and the second is the relative economic cost. Lantada et al. (2010) (as Equation 6) suggested that the absolute economic cost in 1000 millions of Rials due to the damage of residential building contents should be increased fifty percent to estimate the total cost $\left(T_{\text {Cost }}\right)$.

$$
T_{\text {Cost }}=1.5 \times \sum_{k=2}^{5} C S(k)=1.5 \times V_{C} \times \sum_{k=2}^{5} \sum_{j=1}^{n}\left[\operatorname{Area}(j) \times P_{S}(k, j) \times R C(k, j)\right]
$$

where $C S(k)$ is the repairing costs due to the damage state $k$ (absolute cost); $V_{C}$ is the cost per unit area; $\operatorname{Area}(j)$ is the area of the building $j ; P S(k, j)$ is the probability of damage level $k$ on the building $j$; and $R C(k, j)$ is the percentage of the replacement cost per square meter for damage level $k$ in building $j$. The values for $R C(k, j)$ are given by ATC-13 (1985) for each damage level and are taken as $0 \%$ for no damage $(D 0), 2 \%$ for slight damage $(D 1+D 2), 10 \%$ for moderate damage $(D 3), 50 \%$ for severe damage $(D 4)$, and $100 \%$ for complete damage $(D 5)$.

A relative economic cost $R_{\text {Cost }}$ is calculated by Equation 7 .

$$
R_{\text {Cost }}=\frac{\sum_{k=2}^{5} C S(k)}{V_{C}}
$$

Figure 10 shows the economic cost for Kerend-e-gharb city in block scale for both relative (Figure 10a) and absolute total (Figure 10b) expressions. The replacement cost is assumed 22 million Rials per square meter to determine the total cost. As expected, areas with higher seismic vulnerability have a higher economic loss. 

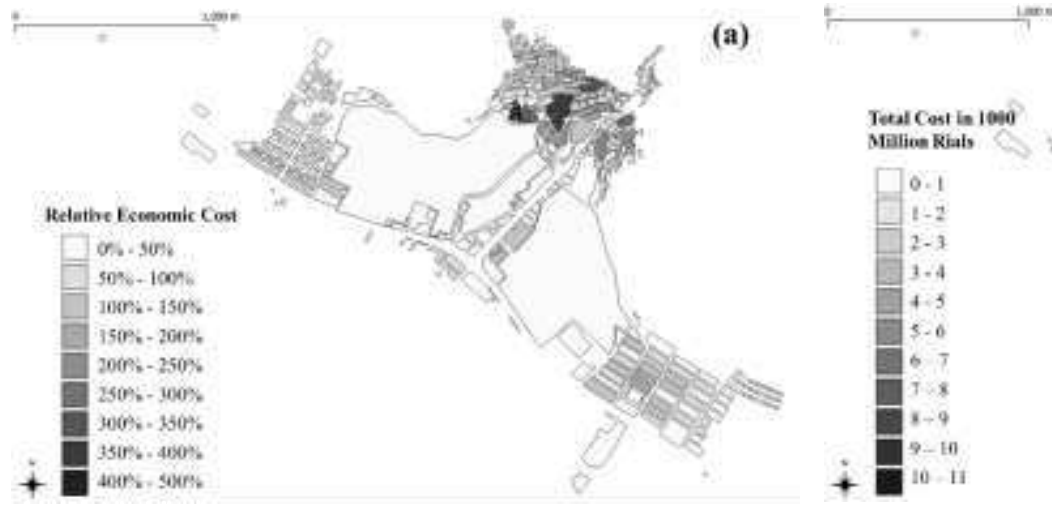

(b)

Figure 10 Economic cost per block: a) relative cost, $R_{\text {Cost; }}$ b) absolute total building reposition cost in 1000 million Rial, $T_{\text {Cost }}$

\section{Debris}

The empirical equations of HAZUS (1999) estimate two different types of debris; small pieces (e.g., bricks, glass, and wood) and large components (e.g., RC elements or steel elements, which should break into smaller pieces before transferring). The generated debris (in tons) is obtained by multiplying the unit weight of structural parts (tons $/ 1000 \mathrm{~m}^{2}$ of floor area) by the percentage of debris generated at each damage state (\% of unit weight of element). HAZUS (1999) presents total debris by Equation 8 .

$$
\text { Total Debris }=\operatorname{Area}(j) \times E D F(i, j)=\operatorname{Area}(j) \times \sum_{k=2}^{5} P(k, j) \times D F(i, k, j)
$$

where $\operatorname{Area}(j)$ is the floor area of building typology $j ; E D F(i, j)$ is the expected debris fraction of debris type $i$ due to structural damage for building typology $j ; P(k, j)$ is the probability of structural damage level $k$ for building typology $j$; and $D F(i, k, j)$ is the debris weight fraction of debris type $i$ for building typology $j$ in structural damage level $k$. Table 4 shows the unit weights of different building materials used in this study adapted from HAZUS (1999). Figure 11 shows the debris amount per block. 
Table 4 Unit weight for structural parts as structural debris and debris generated in fraction of weight at damage state (adopted from HAZUS (1999))

\begin{tabular}{|c|c|c|c|c|c|c|}
\hline \multirow[b]{2}{*}{ Typology } & \multicolumn{2}{|c|}{ Unit weight (ton $\left./ \mathrm{m}^{2}\right)$} & \multicolumn{4}{|c|}{ Debris generated in fraction of weight at damage state } \\
\hline & $\begin{array}{l}\text { Brick, } \\
\text { wood, and } \\
\text { other }\end{array}$ & $\begin{array}{l}\text { Reinforced } \\
\text { concrete and } \\
\text { steel }\end{array}$ & $D 1+D 2$ & D3 & D4 & D5 \\
\hline $\mathrm{RC}$ & 0 & 1.175 & 0 & 0.05 & 0.33 & 1 \\
\hline ST & 0.475 & 0.5 & 0 & 0.04 & 0.3 & 1 \\
\hline $\mathrm{CM}$ & 0.225 & 0.95 & 0.05 & 0.25 & 0.6 & 1 \\
\hline URM & 0.38 & 0.525 & 0.05 & 0.25 & 0.55 & 1 \\
\hline $\mathrm{Ad}$ & 0.38 & 0.525 & 0.05 & 0.25 & 0.55 & 1 \\
\hline
\end{tabular}

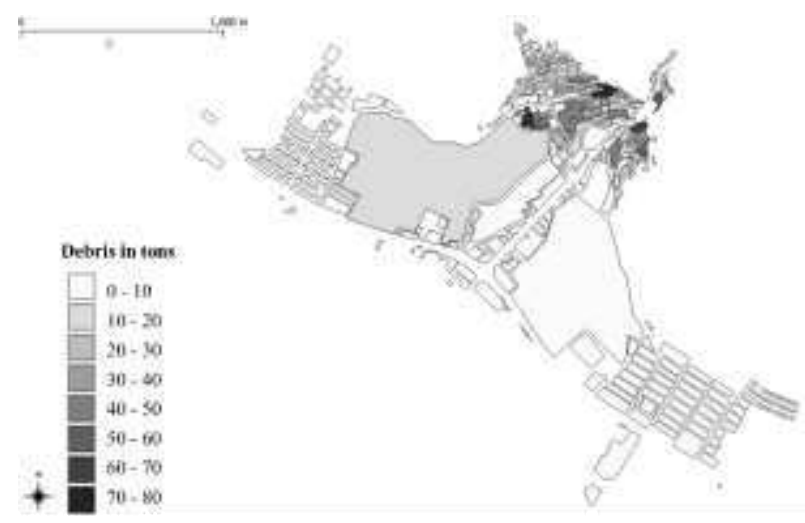

Figure 11 Debris per block in tons

\section{Prediction of the mean damage index in the repetition of the design earthquake}

The most likely damage state of the building (i.e., mean damage grade, $\mu_{\mathrm{D}}$ ) is defined as mean damage index, $D I_{m} . D I_{m}$ is a single parameter used for analyzing and describing the damage distribution which has been adopted to represent the five damage states by Lantada et al. (2010) as described in Equation 9.

$$
D I_{m}=\sum_{k=0}^{5}(k \times P(D k=d))
$$

where $k$ takes the values $0,1,2,3,4$, and 5 for the damage states, and $P(D k)$ represents the probability of occurrence for the damage state $k$. 
Figure 12a shows the mean damage index per block just after Sarpol-e-zahab 2017 earthquake predicted by empirical fragility curves at design earthquake based on the IRSt2800 (2015) standard. A study of mainshocks and aftershocks effects on the structures that have experienced strong ground motions show that exposure to repeated earthquakes may lead to damage accumulation and progressive collapse. In most cases, previous earthquake effects are ignored when calculating the seismic capacity of existing structures. As a result, the probability of structural damage from many mainshock events or aftershocks after the mainshock is considered.

The performance of structures that have experienced strong ground motions in a very short duration after the mainshock is different from when these ground shakings occurred years after the mainshock. As a result, the buildings' performance four years after the Sarpol-e-zahab earthquake differs from their performance before the severe ground motion and in the immediate aftermath of the mainshock. The performance was increased by renovation and remediating interventions for very heavy and destructed damaged buildings ( $D 4$ and $D 5$ ). The performance remains constant for slight and moderate damage buildings (D1 and D2) (Luco et al., 2011). Hence, the previous fragility curves can be used to estimate the prospective damage. The performance of buildings that experienced the heavy damage level (D3) without any structural interventions decreases.

Therefore, the mean damage index of each block needs to be modified depending on the previous earthquake experience. The mean damage index for $D 4$ and $D 5$ damage states is reduced to $D 0$ since these buildings are renovated and retrofitted. The mean damage index for $D 1$ and $D 2$ remains constant and is calculated by previous empirical fragility curves. If the deformation is permanent and structural capacity is reduced from $D 2$ to $D 3$, the mean damage index for $D 3$ increases by the same amount as the difference between the mean damage index of $D 3$ and the mean damage index of $D 2$. Figure 12b shows the prospective design's mean damage index per block four years 
following the earthquake by taking into account the city's redevelopment and retrofitting. Although the situation is more vulnerable for $D 3$ damage state buildings with permanent damage caused by the previous earthquake that were never retrofitted, it is expected that the vulnerabilities would reduce in many locations as a result of the rehabilitation and retrofitting interventions. Most of these vulnerable blocks are in the northeastern part of the city.

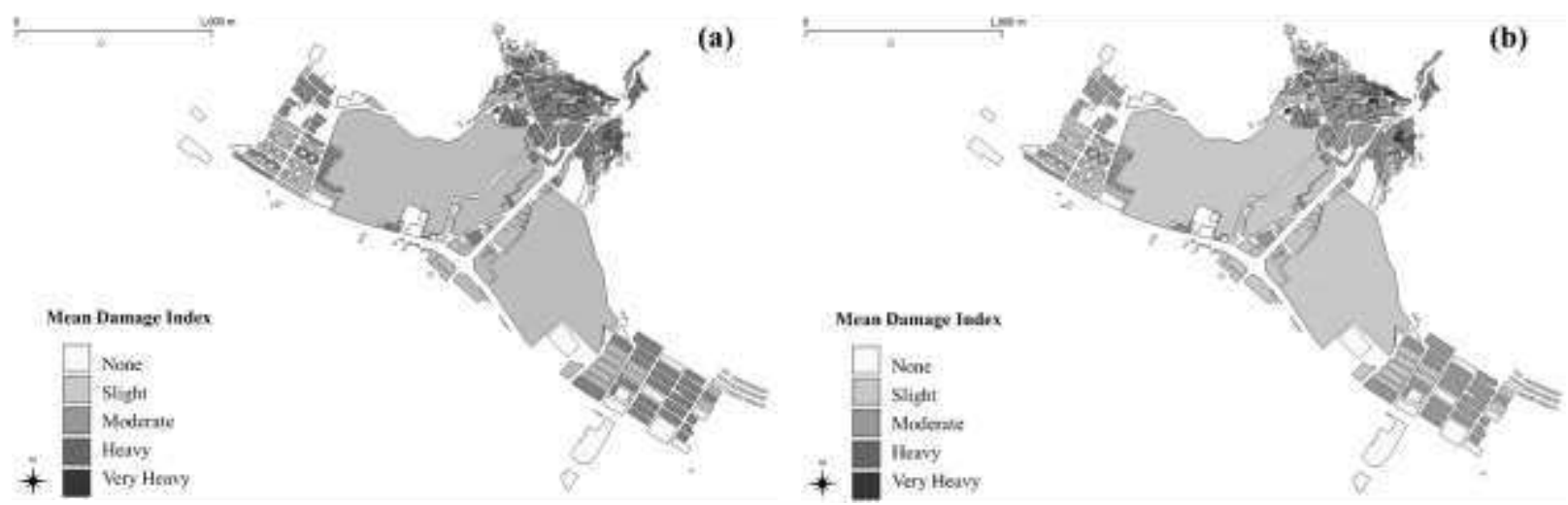

Figure 12 Mean damage index per block: a) 2017 November $12^{\text {th }}$ earthquake; b) prospective design earthquake

\section{Summary and Conclusions}

In this study, the seismic risk of a small mountain city near the western border of Iran, which was affected by the 2017 Sarpol-e-zahab earthquake, was investigated. It includes the seismic vulnerability assessment of buildings at the urban block scale using empirical fragility curves derived from damages under the above-mentioned devastating earthquake. A Geographic Information System (GIS) was utilized to store and display the data. The results have complete agreement with the damage caused by the Sarpol-e-zahab earthquake.

Moreover, the damage to the population, the economic losses, and the debris were assessed. Finally, the mean damage index for each block in the Sarpol-e-zahab earthquake and the most 
probable design earthquake in the future were provided. The findings show that the city's northeast is at high seismic risk, requiring special attention to this area before another severe earthquake.

This study presents the vulnerability of the city blocks and the distribution of human casualties for the emergency management, the rescue, and the provision of necessary treatment systems in each area before the earthquake for preparing a sustainable urban plan.

\section{Acknowledgments}

The authors sincerely wish to thank the Office for International Affairs of Razi Univ., Iran, and the Dept. of Structures for Engineering and Architecture of the University of Naples Federico II, Italy for facilitating the joint research collaboration.

\section{Compliance with Ethical Standards}

Conflict of Interest: Author A declares that she has no conflict of interest. Author B declares that he has no conflict of interest.

Ethical approval: This article does not contain any studies with human participants or animals performed by any of the authors.

\section{References}

Ashayeri I, Biglari M, Sadr A, Haghshenas E (2019) Importance of revisiting (Vs) 30 site class index, Sarpol-e-zahab Mw=7.3 earthquake. In: Proceedings, 7th Int. Conf. on Earthq. Geotech. Eng. 17-20 June 2019, Rome, Italy.

Ashayeri I, Memari MA, Haghshenas E (2021) Seismic Microzonation of Sarpol-e-zahab after Mw 7.3 2017 Iran Earthquake; 1D Equivalent Linear Approach. B Earthq Eng 19(2):605-622. https://doi.org/10.1007/s10518-020-00999-6 
Ashayeri I, Sadr A, Biglari M, Haghshenas E (2020) Comprehensive ambient noise analyses for seismic microzonation of Sarpole-zahab after the Mw 7.3 2017 Iran earthquake. Eng Geol 272. https://doi.org/10.1016/j.enggeo.2020.105636

ATC-13 (1985) Earthquake damage evaluation data for California, ATC-13. Applied Technology Council, Redwood City, California.

Biglari M, Formisano A (2020) Damage probability matrices and empirical fragility curves from damage data on masonry buildings after Sarpol-e-zahab and bam earthquakes of Iran. Front Built Environ. https://doi.org/10.3389/fbuil.2020.00002

Biglari M, Formisano A, Hosseini Hashemi B (2021) Empirical Fragility Curves of Engineered Steel and RC Residential Buildings after Mw 7.3 2017 Sarpol-e-zahab Earthquake. B Earthq Eng 19:2671-2689. https://doi.org/10.1007/s10518-021-01090-4

Biglari M, Kamarizadeh E, Ashayeri I (2018) Evaluation of Seismic Vulnerability of Masonry Buildings without Ties Using the RISK-UE Method, Case Study of Kermanshah City. J Civil Eng (AUT) 2(2):143-152. https://doi.org/10.22060/ajce.2018.14731.5493

Bramerini F, Di Pasquale G, Orsini A, Pugliese A, Romeo R, Sabetta F (1995) Rischio sismico del territorio italiano. Proposta per una metodologia e risultati preliminari. Rapporto tecnico del Servizio Sismico Nazionale, SSN/RT/95/01, Roma (in Italian).

Cherif SE, Chourak M, Abed M, Pujades LG (2016) Seismic risk in the city of Al Hoceima (north of Morocco) using the vulnerability index method, applied in Risk-UE project. Nat Hazards 85:329-347. https://doi.org/10.1007/s11069-016-2566-8 
Chieffo N, Formisano A (2020) Induced Seismic-Site Effects on the Vulnerability Assessment of a Historical Centre in the Molise Region of Italy: Analysis Method and Real Behaviour Calibration Based on 2002 Earthquake. Geosci 10:21. https://doi:10.3390/geosciences10010021

Coburn AW, Spence RJS, Pomonis A (1992) Factors determining human casualty levels in earthquakes: mortality prediction in building collapse', 10th World Conference on Earthquake Engineering, Madrid.

Faccioli E, Frassine L, Finazzi D, Pessina V, Cauzzi C, Lagomarsino S, Giovinazzi S, Resemini S, Curti E, Podestà S, Scuderi S (2004) Synthesis of the application to Catania city. RISK-UE. An advanced approach to earthquake risk scenarios with applications to different European towns. Contract: EVK4-CT-2000-00014.

Gautam D, Rodrigues H (2018) Seismic Vulnerability of Urban Vernacular Buildings in Nepal: Case of Newari Construction. J Earthq Eng 25:43-64. https://doi.org/10.1080/13632469.2018.1498411

Grünthal G (ed.) (1998) Cahiers du Centre Européen de Géodynamique et de Séismologie: Volume 15 - European Macroseismic Scale. Luxembourg: European Center for Geodynamics and Seismology.

HAZUS (1999) Federal Emergency Management Agency. HAZUS user and technical manuals. Federal Emergency Management Agency Report, Washington D.C. 7.

Hessami K, Jamali F, Tabassi H (2003) Major active faults of Iran. International Institute of Earthquake Engineering and Seismology (IIEES) Tehran Iran. 
IRSt2800 (2015) Iranian Code of Practice for Seismic Resistant Design of Buildings, 4th Revision, Building and Housing Research Center, Tehran, IRAN.

Kalantari A, Hashemi BH, Farschi HR (2019) Buildings damage data gathering after 2017 Sarpole-zahab earthquake. Proceedings of the 8th International Conference on Earthquake Engineering and Seismology, Tehran. 11-13.

Kappos AJ, Panagopoulos G, Penelis GG (2008) Development of a seismic damage and loss scenario for contemporary and historical buildings in Thessaloniki, Greece. Soil Dyn Earthq Eng 28:836-850. https://doi.org/10.1016/j.soildyn.2007.10.017

Kostov M, Vaseva E, Kaneva A, Koleva N, Varbanov G, Stefanov D, Darvarova E, Solakov D, Simeonova S, Christoskov L (2004) WP13: application to Sofia. RISK-UE. An advanced approach to earthquake risk scenarios with applications to different European towns. Contract: EVK4-CT2000-00014.

Lantada N, Irizarry J, Barbat AH, Goula X, Roca A, Susagna T, Pujades LG (2010) Seismic hazard and risk scenarios for Barcelona, Spain, using the Risk-UE vulnerability index method. B Earthq Eng 8:201-229. https://doi.org/10.1007/s10518-009-9148-Z

Lestuzzi P, Podestà S, Luchini C, Garofano A, Kazantzidou-Firtinidou D, Bozzano C, Bischof P, Haffter A, Rouiller JD (2016) Seismic vulnerability assessment at urban scale for two typical Swiss cities using Risk-UE methodology. Nat Hazards 84(1):249-269. https://doi.org/10.1007/s11069$\underline{016-2420-\mathrm{Z}}$

Luco N, Gerstenberger MC, Uma SR, Ryu H, Liel AB, Raghunandan M (2011) A methodology for post-mainshock probabilistic assessment of building collapse risk. Proceedings of the Ninth 
Pacific Conference on Earthquake Engineering: Building an earthquake resilient society April 14$16,210$.

Lungu D, Aldea A, Arion A, Cornea T, Petrescu F, Vacareanu R (2004) WP10: synthesis report for the City of Bucharest. Synthesis. RISK-UE. An advanced approach to earthquake risk scenarios with applications to different European towns. Contract: EVK4-CT-2000-00014.

Milutinovic ZV, Trendafiloski GS (2003) RISK-UE,” An Advanced Approach to Earthquake Risk ScenariosWith Applications to Different European Towns, WP4: Vulnerability of current buildings, Contract: EVK4-CT-2000-00014.

Mosoarca M, Onescu I, Onescu E, Azap B, Chieffo N, Szitar-Sirbu M (2019) Seismic vulnerability assessment for the historical areas of the Timisoara city, Romania. Eng Fail Anal 101:86-112. https://doi.org/10.1016/j.engfailanal.2019.03.013

Mouroux P, Le Brun B (2008) RISK-UE Project: an advanced approach to earthquake risk scenarios with application to different European towns. In: Oliveira C.S., Roca A., Goula X. (eds) Assessing and Managing Earthquake Risk. Geotechnical, Geological and Earthquake Engineering 2. Springer, Dordrecht. https://doi.org/10.1007/978-1-4020-3608-8_23

Omidvar B, Gatmiri B, Derakhshan S (2012) Experimental vulnerability curves for the residential buildings of Iran. Nat Hazards 60:345-365; https://doi.org/10.1007/s11069-011-0019-y

QGIS (2014) Development Team, QGIS Geographic Information System. Open Source Geospatial Foundation Project. Retrieved from: http://qgis.osgeo.org.Qgisorg.doi:http://www.qgis.org/ 
Vicente R, Parodi S, Lagomarsino S, Varum H, Silva JARM (2011) Seismic vulnerability and risk assessment: case study of the historic city centre of Coimbra, Portugal. B Earthq Eng 9:10671096. https://doi.org/10.1007/s10518-010-9233-3 